\title{
Differential expression of pathogenicity- and virulence-related genes of Xanthomonas axonopodis pv. citri under copper stress
}

\author{
Ana Carolina Basílio Palmieri ${ }^{1}$, Alexandre Morais do Amaral ${ }^{1,2}$, Rafael Augusto Homem ${ }^{1,3}$ \\ and Marcos Antonio Machado ${ }^{1}$ \\ ${ }^{1}$ Centro APTA Citros Sylvio Moreira, Instituto Agronômico de Campinas, Cordeirópolis, SP, Brazil. \\ ${ }^{2}$ Embrapa Recursos Genéticos e Biotecnologia Brasília, DF, Brazil. \\ ${ }^{3}$ Instituto de Biologia, Universidade Estadual de Campinas, Campinas, SP, Brazil.
}

\begin{abstract}
In this study, we used real-time quantitative PCR (RT-qPCR) to evaluate the expression of 32 genes of Xanthomonas axonopodis pv. citri related to pathogenicity and virulence that are also involved in copper detoxification. Nearly all of the genes were up-regulated, including copA and copB. Two genes homologous to members of the type II secretion system $(x c s H$ and $x c s C$ ) and two involved in the degradation of plant cell wall components (pglA and $p e l)$ were the most expressed in response to an elevated copper concentration. The type II secretion system (xcs operon) and a few homologues of proteins putatively secreted by this system showed enhanced expression when the bacteria were exposed to a high concentration of copper sulfate. The enhanced expression of the genes of secretion II system during copper stress suggests that this pathway may have an important role in the adaptative response of $X$. axonopodis pv. citri to toxic compounds. These findings highlight the potential role of these genes in attenuating the toxicity of certain metals and could represent an important means of bacterial resistance against chemicals used to control diseases.
\end{abstract}

Key words: copper resistance, citrus canker, real-time quantitative PCR.

Received: February 2, 2009; Accepted: October 14, 2009.

The genus Xanthomonas includes pathogenic bacteria that are highly damaging to a number of economically important plant hosts, including citrus species. Xanthomonas axonopodis pv. citri is the cause of citrus canker, with most commercial citrus varieties being moderately to highly susceptible to this disease. Typical symptoms of citrus canker are circular, necrotic spots with a water-soaked margin surrounded by a yellow halo on leaves and fruits. Heavily affected plants suffer defoliation, dieback and fruit drop.

The main strategies for controlling citrus canker include quarantine measures to prevent the introduction and establishment of bacteria in orchards, and the use of copper compounds to reduce contamination and dissemination of the disease. The use of copper sprays is a major preventive measure in most integrated management programs. The application of copper to young citrus leaves protects against infection, but this protection is quickly lost because of the fast expansion of the leaf surface area. Indeed, copper compounds are less effective in preventing leaf infection than in

Send correspondence to Marcos Antonio Machado. Centro APTA Citros Sylvio Moreira, Instituto Agronômico de Campinas, Caixa Postal 4, 13490-970 Cordeirópolis, SP, Brazil. E-mail: marcos@centrodecitricultura.br. preventing fruit infection, primarily because of the slower growth rate of the latter.

Copper induces metabolic changes in several plantassociated bacteria, such as Rhizobium leguminosarum, Agrobacterium tumefaciens, Ralstonia solanacearum, Xanthomonas campestris pv. campestris, and Erwinia amylovora, as part of the survival strategy of these microorganisms (Alexander et al., 1999; Colwell, 2000; Grey and Steck, 2001a,b: da Silva et al., 2002). X. axonopodis pv. citri contains homologues to genes ( $\operatorname{cop} A, \operatorname{cop} B, \operatorname{cutC}$ and $d s b D$ ) that are closely related to resistance against toxic levels of copper in other xanthomonads and Pseudomonas syringae (Lee at al., 1994; Mellano and Cooksey, 1988; Mills et al., 1993; Voloudakis et al., 2005; Teixeira et al., 2008). Much of the information available on the factors that affect $X$. axonopodis pv. citri and its response to copper has been deduced from other bacteria (Basim et al., 2005; Voloudakis et al., 2005). However, recently, the operon cop AB of $X$. axonopodis pv. citri was shown to involved in the copper resistance of this species (Teixeira et al., 2008).

We have previously reported the expression of 279 genes of $X$. axonopodis pv. citri putatively involved in modulating the pathogenicity and virulence of this species, including resistance to toxic compounds (Astua-Monge et 
al., 2005). To understand the global response of $X$. axonopodis pv. citri to copper, we used real-time quantitative PCR to examine the profile of 32 of the 279 genes putatively associated with pathogenicity and virulence. Almost all of the genes were up-regulated. Two genes homologous to members of the type II secretion system $(x c s \mathrm{H}$ and $x c s \mathrm{C})$ and two involved in the degradation of plant cell wall components ( $\mathrm{pgl \textrm {A }}$ and $\mathrm{pel}$ ) were the genes most expressed in response to an elevated concentration of copper.

To examine the gene expression in response to a high concentration of copper in vitro, $X$. axonopodis pv. citri strain 306 was grown overnight in $200 \mathrm{~mL}$ of nutrient broth (5 $\mathrm{g}$ of peptone/L and $3 \mathrm{~g}$ of meat extract/L, $\mathrm{pH} 7.0$ ) and then centrifuged $\left(10,000 \times \mathrm{x}, 4^{\circ} \mathrm{C}, 15 \mathrm{~min}\right)$. The bacteria were harvested and resuspended in $285 \mathrm{~mL}$ of $\mathrm{M} 9$ minimum medium $\left(\mathrm{Na}_{2} \mathrm{HPO}_{4} 6 \mathrm{~g} / \mathrm{L}, \mathrm{KH}_{2} \mathrm{PO}_{4} 3 \mathrm{~g} / \mathrm{L}, \mathrm{NaCl}\right.$ $0.5 \mathrm{~g} / \mathrm{L}$ and $\mathrm{NH}_{4} \mathrm{Cl} 1 \mathrm{~g} / \mathrm{L}$ ) to which $0.2 \mathrm{mM} \mathrm{CuSO}_{4}$ was added after filtration through a $0.45 \mu \mathrm{m}$ filter; this concentration of $\mathrm{CuSO}_{4}$ corresponded to the minimum inhibitory concentration (MIC) and was determined by growing bacteria in M9 medium supplemented with 0.04, 0.08, 0.12 and $0.20 \mathrm{mM} \mathrm{CuSO}_{4}$. Control cultures contained the same medium but without copper. The cultures were incubated at $28{ }^{\circ} \mathrm{C}$ overnight with shaking $(100 \mathrm{rpm})$ and aliquots of $50 \mathrm{~mL}$ were harvested after 2, 4, 6, 8, 10 and $12 \mathrm{~h}$, centrifuged and stored at $-80^{\circ} \mathrm{C}$. The six samples were subsequently pooled and used for RNA extraction. All of the experiments were done in triplicate.

Total RNA was extracted by lysing the bacterial cells with lysozyme $(0.5 \mathrm{mg} / \mathrm{mL}$ in Tris-HCl/EDTA buffer, $\mathrm{pH}$ 8.0) followed by incubation with $10 \% \mathrm{SDS}$ at $64^{\circ} \mathrm{C}$ and treatment with chloroform. The RNA samples were treated with DNase (DNase I Amp Grade, Invitrogen) according to the manufacturers instructions followed by purification with phenol, phenol:chloroform $(50: 50, \mathrm{v} / \mathrm{v})$ and chloroform. Finally, the RNA samples were precipitated with $3 \mathrm{M}$ sodium acetate and $100 \%$ cold ethanol and stored at $-80{ }^{\circ} \mathrm{C}$ until required. Contamination by DNA was confirmed by PCR using specific primers for the gene avrXacE1 from $X$. axonopodis pv. citri.

cDNA was synthesized in random hexamer-primed reactions from approximately $5 \mu \mathrm{g}$ of DNase I-treated RNA by single-step reverse transcription RT-PCR done according to the protocol provided by Invitrogen for M-MLV. Briefly, to each RNA sample were added $0.5 \mu \mathrm{L}$ of random primer $(3 \mu \mathrm{g} / \mu \mathrm{L}), 1 \mu \mathrm{L}$ of $10 \mathrm{mM}$ dNTPs and DEPCtreated water to a final volume of $12 \mu \mathrm{L}$. The samples were incubated at $68^{\circ} \mathrm{C}$ for $15 \mathrm{~min}$ and then immediately placed on ice for $3 \mathrm{~min}$. A second reaction was prepared by using $5 \mathrm{X}$ first-strand buffer, 0.1 M DTT, RNase-out and M-MLV reverse transcriptase followed by incubation in a water bath $37^{\circ} \mathrm{C}$ for $1 \mathrm{~h}$.

The level of abundance of the pathogenicity-related genes $a c v B$, avrBs2, avrXacE1, avrXacE2, celD, copA, сорB, сutC, еgl, guтB, gumG, guтM, hpaA, hrcR, hrcT,
hrpB1, hrpG, ostA, pel, pglA, rpfC, rpfE, rpfF, virB8, virD4, virK, $x a n B, x c s C, x c s H, x p s D$, xpsL, and $x r v A$, and transcripts over time relative to the $\operatorname{lrp}$ gene (leucine-responsive regulatory protein gene, used as an internal control) was analyzed by RT-qPCR. Primers for PCR were designed to amplify internal fragments of 100-200 bp in each open reading frame (Table 1) and were tested for amplification specificity and efficiency. Each reaction was done in a total volume of $25 \mu \mathrm{L}$ that contained $1 \mu \mathrm{L}$ of cDNA $(60 \mathrm{ng} / \mu \mathrm{L}), 2.5 \mathrm{mM}$ of each primer and $12.5 \mu \mathrm{L}$ of SYBR Green PCR Master Mix kit (PE Applied Biosystems, Foster City, CA). The cycling conditions used were $2 \mathrm{~min}$ at $50^{\circ} \mathrm{C}, 10 \mathrm{~min}$ at $95^{\circ} \mathrm{C}$ and 40 cycles of $30 \mathrm{~s}$ at $95^{\circ} \mathrm{C}$ and $1 \mathrm{~min}$ at $60^{\circ} \mathrm{C}$, with a final extension of $10 \mathrm{~min}$ at $72^{\circ} \mathrm{C}$. The cDNA was quantified with an ABI Prism 7500 sequence detection system (PE Applied Biosystems). The comparative cycle threshold method was used to analyze the data, as described by the manufacturer (PE Applied Biosystems). The $\Delta \Delta \mathrm{Ct}$ method was used to calculate the relative amount of specific RNA present in a sample, from which the fold induction of gene transcription was estimated by comparison to the values for control colonies grown in the same minimal medium but with no addition of copper. Each PCR was done in triplicate and the mean data from 2-3 experimental replicates are reported.

Although a number of $X$. axonopodis pv. citri genes have been implicated in processes related to detoxification (da Silva et al., 2002), little is known about the regulation of the copper stress response in this species. A better understanding of the pathways involved in resistance to copper could be useful in identifying potential target genes for further studies. In this work, we used qPCR to examine the response of $X$. axonopodis pv. citri after exposure to an elevated concentration of copper sulfate for up to $12 \mathrm{~h}$. The genes investigated here were chosen based on the results of a previous study that used DNA macroarrays (AstuaMonge et al., 2005) (Table 1).

The level of gene expression was estimated based on the cycle threshold $(\mathrm{Ct})$ values and the use of standard curves. In all cases, the data were normalized relative to the constitutively expressed lrp gene. The lrp gene encodes a major transcriptional regulatory protein involved in the control of at least 75 genes in E. coli (Newman et al., 1992), and Lrp homologues are involved in the regulation of amino acid metabolism (Brinkman et al., 2003). This gene was chosen as an internal control because previous experiments had shown that its transcript levels were not significantly altered compared to those of other genes ( $p t h A$, rpo, $n u o B$, petC and $16 \mathrm{~S}$ rRNA). In addition, this gene is universally present in Xanthomonas spp. and has been used to assess the phylogenetic relationships within this genus (Cubero and Graham, 2004, 2005).

In the present study, some of the operons chosen for analysis were clusters from which the initial, central and terminal genes were used to monitor transcription. Overall, 
Table 1 - ORF names, primers for quantitative PCR (qPCR) and transcript levels of pathogenicity and virulence genes of Xanthomonas axonopodis pv. citri grown under copper stress.

\begin{tabular}{|c|c|c|c|c|c|}
\hline ORF name & $\begin{array}{l}\text { Protein name Forward }(\mathrm{F}) \\
\text { and reverse }(\mathrm{R}) \text { primers }\end{array}$ & $\begin{array}{c}\text { Fold } \\
\text { increase } \pm \mathrm{SD}^{\mathrm{a}}\end{array}$ & ORF name & $\begin{array}{l}\text { Protein name Forward }(\mathrm{F}) \\
\text { and reverse }(\mathrm{R}) \text { primers }\end{array}$ & $\begin{array}{c}\text { Fold } \\
\text { increase } \pm \mathrm{SD}^{\mathrm{a}}\end{array}$ \\
\hline$a c v B$ & $\begin{array}{l}\text { Virulence protein } \\
\mathrm{F}-\text { tgcaactggtccatgatcg } \\
\mathrm{R}-\text { gacggtgtgcatctacgg }\end{array}$ & $0.29 \pm 0.05$ & ost $A$ & $\begin{array}{l}\text { Trehalose-6-phosphate synthase } \\
\text { F - gaaatgaaggaagcgttgc } \\
\text { R - agagagcgcttgcagatagc }\end{array}$ & $0.19 \pm 0.03$ \\
\hline avrBs 2 & $\begin{array}{l}\text { Avirulence protein } \\
\mathrm{F} \text { - agacaacgcgatcacacc } \\
\mathrm{R} \text { - caatccgtctccgtctgc }\end{array}$ & $0.79 \pm 0.22$ & pel & $\begin{array}{l}\text { Pectate lyase } \\
\mathrm{F} \text { - caacgtgttcgagatcagc } \\
\mathrm{R} \text { - tttcgccttgacgtctgc }\end{array}$ & $5.29 \pm 0.72$ \\
\hline avrXacE1 & $\begin{array}{l}\text { Avirulence protein } \\
\mathrm{F}-\text { acagcgatcctgaaagacg } \\
\mathrm{R}-\text { cttcgataccagaaagcctgc }\end{array}$ & $0.37 \pm 0.25$ & pglA & $\begin{array}{l}\text { Polygalacturonase } \\
\text { F - acttcaccttcaagggtggc } \\
\text { R - cggcagtaccgagtgatagg }\end{array}$ & $1.89 \pm 0.28$ \\
\hline avrXacE2 & $\begin{array}{l}\text { Avirulence protein } \\
\mathrm{F} \text { - ctgaggaagtctggcaacc } \\
\mathrm{R}-\text { cgcttgctgctttcttgc }\end{array}$ & $0.40 \pm 0.26$ & $r p f C$ & $\begin{array}{l}\text { Regulation pathogenicity factor } \mathrm{C} \\
\mathrm{F} \text { - acagttgaagaccggactgg } \\
\mathrm{R} \text { - tcagggatcgccattacc }\end{array}$ & $0.26 \pm 0.24$ \\
\hline celD & $\begin{array}{l}\text { Glucan 1,4-beta-glucosidase } \\
\mathrm{F} \text { - gatgtgaccaagctgaccc } \\
\mathrm{R} \text { - tacttgaccgggcagtcg }\end{array}$ & $0.07 \pm 0.06$ & $r p f E$ & $\begin{array}{l}\text { Regulatory protein } \\
\mathrm{F} \text { - tggtgttggacttccagg } \\
\mathrm{R} \text { - cattgcgecagctgtacc }\end{array}$ & $0.13 \pm 0.04$ \\
\hline copA & $\begin{array}{l}\text { Copper resistance protein A precursor } \\
\text { F - aacttccaggtacgcaagc } \\
\text { r- catgtggtacagcagatggc }\end{array}$ & $0.10 \pm 0.06$ & $r p f F$ & $\begin{array}{l}\text { Regulation pathogenicity factor } F \\
\mathrm{~F} \text { - gtacctggccatgaatgc } \\
\mathrm{R} \text { - gcagcgacttttcattgagc }\end{array}$ & $0.14 \pm 0.02$ \\
\hline $\operatorname{cop} B$ & $\begin{array}{l}\text { Copper resistance protein B precursor } \\
\mathrm{F} \text { - ggcgaatacgaggtactgc } \\
\mathrm{R} \text { - gcatccagccgatgtacg }\end{array}$ & $0.46 \pm 0.08$ & $\operatorname{vir} B 8$ & $\begin{array}{l}\text { Type IV system protein B8 } \\
\mathrm{F}-\text { atttcctgatcaaatgcagc } \\
\mathrm{R} \text { - tcatcgaccacttgctcc }\end{array}$ & $0.37 \pm 0.10$ \\
\hline cutC & $\begin{array}{l}\text { Copper homeostasis protein } \\
\mathrm{F} \text { - tttccgagcacaacatcc } \\
\mathrm{R} \text { - gtccaccatccgttgtacc }\end{array}$ & $0.07 \pm 0.01$ & $\operatorname{virD4}$ & $\begin{array}{l}\text { Type IV system protein D4 } \\
\mathrm{F} \text { - catagcgtgtcagaagaacg } \\
\mathrm{R} \text { - gatggtaagcgtcttcacttcg }\end{array}$ & $0.09 \pm 0.01$ \\
\hline$E g l$ & $\begin{array}{l}\text { Cellulase } \\
\mathrm{F} \text { - atggaaaagaacagcgacg } \\
\mathrm{R}-\text { cgtgcgtacttgctcagg }\end{array}$ & $0.18 \pm 0.02$ & $\operatorname{virK}$ & $\begin{array}{l}\text { VirK protein } \\
\mathrm{F}-\text { agcagttcatgcgctacc } \\
\mathrm{R} \text { - gcattgatcttgcattgatacg }\end{array}$ & $0.19 \pm 0.04$ \\
\hline gumB & $\begin{array}{l}\text { GumB protein } \\
\mathrm{F}-\text { atcctgagatctatggcgg } \\
\mathrm{R}-\text { gccacaccatcacaagagg }\end{array}$ & $0.21 \pm 0.00$ & $x a n B$ & $\begin{array}{l}\text { Phosphomannose isomerase/ } \\
\text { GDP-mannose pyrophosphorylase } \\
\text { F - aaccagagcacctacatccc } \\
\text { R - ataatcgtcttcgcccagatagc }\end{array}$ & $0.04 \pm 0.03$ \\
\hline gumG & $\begin{array}{l}\text { GumG protein } \\
\mathrm{F} \text { - gattctgtgcacgcatacc } \\
\mathrm{R} \text { - catttgcgtttcaacccc }\end{array}$ & $0.46 \pm 0.03$ & $x c s C$ & $\begin{array}{l}\text { Type II secretion system protein C } \\
\mathrm{F} \text { - gctgacccagatcaatgg } \\
\mathrm{R} \text { - gcttcaaggtcatggtgtgg }\end{array}$ & $4.72 \pm 0.64$ \\
\hline gumM & $\begin{array}{l}\text { GumM protein } \\
\mathrm{F} \text { - gcatatggaatggatgtatcg } \\
\mathrm{R} \text { - caggtgcggaagaacacc }\end{array}$ & $0.08 \pm 0.08$ & $x c s H$ & $\begin{array}{l}\mathrm{K} \text { - gcttcaaggtcatggtgtgg } \\
\text { Type II secretion system protein } \mathrm{H} \\
\mathrm{F} \text { - atcgccttggatgaaacg }\end{array}$ & $5.72 \pm 0.15$ \\
\hline hpaA & $\begin{array}{l}\text { Type III secretion system protein } \\
\mathrm{F} \text { - acgcaattttcacctattgc } \\
\mathrm{R} \text { - ctcaatcagtagtgtgttcagacg }\end{array}$ & $0.35 \pm 0.19$ & $x p s D$ & $\begin{array}{l}\mathrm{R} \text { - catcgacctgcactacgc } \\
\text { General secretion pathway protein } \mathrm{G} \\
\mathrm{F} \text { - ccttcaattgtgcgtaatcc }\end{array}$ & $0.03 \pm 0.01$ \\
\hline$h r c R$ & $\begin{array}{l}\text { Type III secretion system protein } \mathrm{R} \\
\mathrm{F} \text { - ggtgtttatcgtcatcgacc } \\
\mathrm{R} \text { - accgatagctcagaaccagg }\end{array}$ & $1.83 \pm 0.23$ & $x p s L$ & $\begin{array}{l}\mathrm{R} \text { - atttccatcccgacttatcg } \\
\text { General secretion pathway protein } \mathrm{L} \\
\mathrm{F} \text { - cctggtggtacgtatctgg }\end{array}$ & $1.17 \pm 1.12$ \\
\hline$h r c T$ & $\begin{array}{l}\text { Type III secretion system protein } \mathrm{T} \\
\mathrm{F} \text { - aatttgagtcagccaatccg } \\
\mathrm{R} \text { - caattgctgctggaaatgc }\end{array}$ & $0.61 \pm 0.24$ & $x r v A$ & $\begin{array}{l}\mathrm{R} \text { - gtgatggtgaagcggtcg } \\
\text { Virulence regulator } \\
\mathrm{F} \text { - aaggaagtggtcaagagcg }\end{array}$ & $0.05 \pm 0.01$ \\
\hline hrpBI & Type III secretion system protein B1 & $0.79 \pm 0.10$ & & K-aaccagcggaaacttgagg & \\
\hline
\end{tabular}

F - gctgatcgaagaagacgc

$\mathrm{R}$ - caggcacgcaggtattgc

hrpG Type III secretion system protein $\mathrm{G}$ F - cagcacatctacaagttgeg

$\mathrm{R}-$ ccttgctcattgtcgttgc

${ }^{a}$ Fold increase in the level of gene expression compared to the control \pm standard deviation (SD). 
gene expression in the presence of copper was up-regulated by $0.03-5.72$ fold (Table 1 ).

RT-qPCR indicated that the transcripts of two transporters $(x \operatorname{cs} C$ and $x c s H)$ and a protein involved in the degradation of plant cell wall components (pel) were nearly five-fold higher in medium containing copper compared to that without copper. In addition, the expression of $\mathrm{pglA}$, another homologous protein involved in the degradation of plant cell wall components, was approximately two-fold higher in the presence of copper. The $\operatorname{cop} A$ and $\operatorname{cop} B$ genes, which are directly associated with copper resistance (Russel, 1998), also showed enhanced expression in the presence of copper, but at a lower level than for transporter $(x c s \mathrm{H}$ and $x c s \mathrm{C})$ and exoenzyme (pglA and $p e l)$ genes.

The homologue genes $x c s H$ and $x c s C(\mathrm{OK})$ encode putative transport proteins of the type II secretory apparatus involved in the translocation of exoproteins from the cytoplasm to the periplasm. Interestingly, all of the other homologous proteins, i.e., those involved in degrading plant cell wall components, that showed higher expression during copper stress may also be translocated by the type II secretion systems (Russel, 1998; Jha et al., 2005; Johnson et al., 2006).

Although most of the genes examined here were only slightly up-regulated, a set of four genes related to pathogenicity and virulence showed markedly enhanced expression, including two type II secretion system components and two genes involved in degrading components of plant cell walls. These genes are associated with pathogenicity and virulence-related genes of $X$. axonopodis pv. citri identified in hrp-inducing medium (XVM2) (Astua-Monge et al., 2005). Since it is not feasible to reproduce in vitro the restrictive environmental conditions required to identify all of the $X$. axonopodis pv. citri genes involved in plant colonization there is a need for individual analysis of the key virulence factors involved in this process.

The type II secretion system is used by various Gram-positive bacteria to transport a large number of secreted proteins, including major virulence factors (such as pectate lyases, cellulases, proteases, toxins and alkaline phosphatases) and other proteins associated with the induction of plant defense responses, from the periplasmic space to the extracellular environment (Russel, 1998; Jha et al., 2005; Johnson et al., 2006). Interestingly, $X$. axonopodis pv. citri contains two copies (xps and xcs operons) of this machinery, but there is no homology between the two clusters. Although X. axonopodis pv. citri harbors two type II secretion systems ( $x p s$ and $x c s$ ), only $x c s$ was expressed to a significant extent. These two systems are probably involved in the secretion of different exoproteins, as in Pseudomonas aeruginosa, which has two functional type II systems (Filloux et al., 1998; Ball et al., 2002). Despite the fact that bacterial secretion systems are important for host-pathogen interactions, in many bacteria the type II secretion system is responsible for the transport of a number of virulence-associated proteins (Iwobi et al., 2003; Arrieta et al., 2004; Rossier et al., 2004; Soderberg et al., 2004).

In $X$. axonopodis $\mathrm{pv}$. citri the cop $A B$ operon is specifically induced by copper (Teixeira et al., 2008). We also observed up-regulation of $\operatorname{cop} \mathrm{A}$ and $\operatorname{cop} \mathrm{B}$, but to a lower extent than for genes associated with secretion systems. Neither of the transcripts was detected in incubations without copper but showed enhanced expression in the presence of this metal (Table 1). Since $X$. axonopodis pv. citri is copper-sensitive, the apparent difference in the expression of $\operatorname{cop} \mathrm{A}$ and $\operatorname{cop} \mathrm{B}$ may be related to the method of transcript detection (northern blot versus RT-qPCR) or to the activity of copper in the medium. In our experiments, the MIC was estimated in inorganic medium (M9) that lacked chelating agents usually present in organic media such as TSA (1\% trypone, $1 \%$ sucrose and $0.1 \%$ sodium glutamate) or nutrient broth (see Material and Methods). On the other hand, there could be a direct relationship between the external concentration of copper and expression of the cop $\mathrm{AB}$ operon. Since the MIC values obtained using different culture media cannot be compared, the corresponding levels of gene expression are also not directly comparable. Despite the absence of $\operatorname{cop} C$ and $\operatorname{copD}$ in the cop operon of $X$. axonopodis pv. citri, the bacteria were apparently able to detoxify copper at low concentrations that affected growth but did not kill the cells.

Although a lack of growth in the presence of high levels of copper is generally considered to be indicative of cell death, this absence of growth could also result from the cells entering the viable but non-culturable (VBNC) state (Grey and Steck, 2001b). This state is defined as one in which cells are viable but do not undergo sufficient division to allow visible growth in non-selective media (Colwell, 2000). After exposure to a high concentration of copper sulfate, E. amylovora cells in the VBNC state regained their ability to grow and their pathogenicity (Ordax et al., 2006). Our results indicate that copper may cause $X$. axonopodis pv. citri to enter the VBNC state.

In contrast to Cupriavidus metallidurans, a model organism remarkable for its copper-resistance in which exposure to elevated $\mathrm{Cu}(\mathrm{II})$ concentrations results in gene inductions of 2- to 1159-fold (Monchy et al., 2006), the copper-resistance genes of $X$. axonopodis pv citri were only slighly up-regulated by exposure to copper. In $E$. amylovora, another bacterial plant pathogen, the MIC of copper sulfate in solid medium was $3.5 \mathrm{mM} \mathrm{Cu}^{2+}$, which was 70 times higher than the highest copper concentration $\left(0.05 \mathrm{mM} \mathrm{Cu}^{2+}\right)$ used in the survival experiments (Ordax et al., 2006). In Xanthomonas campestris pv. juglandis, the expression of all four ORFs (copABCD) that showed homology with the operons for tolerance against copper was increased following exposure to copper; this enhanced expression was required for full resistance to this metal (Lee et al., 1994). 
In some organisms, the cop operon is induced by copper, which allows growth in the presence of high levels of copper compounds (up to $5 \mathrm{mM}$ ) used for disease control in agricultural crops. In C. metallidurans, a bacterial species with a notorious resistance to metals, resistance to copper is represented by two gene clusters that putatively encode periplasmic resistance (copSRABCD and copVTMKNSRABCDIJGFLQHE), with maximal expression at $0.4 \mathrm{mM} \mathrm{Cu}$ (Monchy et al., 2006).

In conclusion, the results described here indicate that exposure to copper induces the differential expression of several pathogenicity-related genes in $X$. axonopodis pv. citri. The most highly induced genes (such as the $x c s$ operon, pel and $p g l A$ ) are related to high levels of copper and transport, whereas the genes involved in other activities showed a lower level of induction. The responsive genes $x c s \mathrm{C}$ and $x c s \mathrm{H}$ are members of the type II secretion system, which confirms the importance of this system in the response to copper compounds in $X$. axonopodis pv. citri. Whether the enhanced expression of these genes in response to a high copper concentration is associated with a mechanism of detoxification or is simply a response to the presence of copper as a co-factor remains to be determined. The identification of a type II secretion system as a component involved in the response of $X$. axonopodis pv. citri is an essential step towards a more comprehensive understanding of the role of these genes in bacterial adaptation to copper-induced stress.

\section{Acknowledgments}

The authors thank PRODETAB and FAPESP for financial support. AMA and MAM are supported by research fellowships from CNPq.

\section{References}

Alexander E, Pham D and Steck TR (1999) The viable but nonculturable condition is induced by copper in Agrobacterium tumefaciens and Rhizobium leguminosarum. Appl Environ Microbiol 65:3754-3756.

Arrieta JG, Sotolongo M, Menendez C, Alfonso D, Trujillo LE, Soto M, Ramirez R and Hernandez L (2004) A type II protein secretory pathway required for levansucrase secretion by Gluconacetobacter diazotrophicus. J Bacteriol 186:5031-5039.

Astua-Monge G, Freitas-Astua J, Bacocina G, Roncoletta J, Carvalho SA and Machado MA (2005) Expression profiling of virulence and pathogenicity genes of Xanthomonas axonopodis pv. citri. J Bacteriol 187:1201-1205.

Ball G, Durand E, Lazdunski A and Filloux A (2002) A novel type II secretion system in Pseudomonas aeruginosa. Mol Microbiol 43:475-485.

Basim H, Minsavage GV, Stall RE, Wang JF, Shanker S and Jones JB (2005) Characterization of a unique chromosomal copper resistance gene cluster from Xanthomonas campestris pv. vesicatoria. Appl Environ Microbiol 71:8284-8291.
Brinkman AB, Ettema TJ, de Vos WM and van der Oost J (2003) The Lrp family of transcriptional regulators. Mol Microbiol 48:287-294.

Colwell RR (2000) Viable but nonculturable bacteria: A survival strategy. J Infect Chemother 6:121-125.

Cubero J and Graham JH (2004) The leucine-responsive regulatory protein (lrp) gene for characterization of the relationship among Xanthomonas species. Int J Syst Evol Microbiol 54:429-437.

Cubero J and Graham JH (2005) Quantitative real-time polymerase chain reaction for bacterial enumeration and allelic discrimination to differentiate Xanthomonas strains on citrus. Phytopathology 95:1333-1340.

da Silva AC, Ferro JA, Reinach FC, Farah CS, Furlan LR, Quaggio RB, Monteiro-Vitorello CB, Van Sluys MA, Almeida NF, Alves LM et al. (2002) Comparison of the genomes of two Xanthomonas pathogens with differing host specificities. Nature 417:459-463.

Filloux A, Michel G and Bally M (1998) GSP-dependent protein secretion in gram-negative bacteria: The Xcp system of Pseudomonas aeruginosa. FEMS Microbiol Rev 22:177198.

Grey BE and Steck TR (2001a) Concentrations of copper thought to be toxic to Escherichia coli can induce the viable but nonculturable condition. Appl Environ Microbiol 67:53255327.

Grey BE and Steck TR (2001b) The viable but nonculturable state of Ralstonia solanacearum may be involved in long-term survival and plant infection. Appl Environ Microbiol 67:3866-3872.

Iwobi A, Heesemann J, Garcia E, Igwe E, Noelting C and Rakin A (2003) Novel virulence-associated type II secretion system unique to high-pathogenicity Yersinia enterocolitica. Infect Immun 71:1872-1879.

Jha G, Rajeshwari R and Sonti RV (2005) Bacterial type two secretion system secreted proteins: Double-edged swords for plant pathogens. Mol Plant Microbe Interact 18:891-898.

Johnson TL, Abendroth J, Hol WG and Sandkvist M (2006) Type II secretion: From structure to function. FEMS Microbiol Lett 255:175-186.

Lee YA, Hendson M, Panopoulos NJ and Schroth MN (1994) Molecular-cloning, chromosomal mapping, and sequenceanalysis of copper-resistance genes from Xanthomonas campestris pv.juglandis: Homology with small blue copper proteins and multicopper oxidase. J Bacteriol 176:173-188.

Mellano MA and Cooksey DA (1988) Induction of the copper resistance operon from Pseudomonas syringae. J Bacteriol 170:4399-4401.

Mills SD, Jasalavich CA and Cooksey DA (1993) A twocomponent regulatory system required for copper-inducible expression of the copper resistance operon of Pseudomonas syringae. J Bacteriol 175:1656-1664.

Monchy S, Benotmane MA, Wattiez R, van Aelst S, Auquier V, Borremans B, Mergeay M, Taghavi S, van der Lelie D and Vallaeys T (2006) Transcriptomic and proteomic analyses of the pMOL30-encoded copper resistance in Cupriavidus metallidurans strain CH34. Microbiology 152:1765-1776.

Newman EB, D'Ari R and Lin RT (1992) The leucine-Lrp regulon in E. coli: A global response in search of a raison d'être. Cell 68:617-619. 
Ordax M, Marco-Noales E, Lopez MM and Biosca EG (2006) Survival strategy of Erwinia amylovora against copper: Induction of the viable-but-nonculturable state. Appl Environ Microbiol 72:3482-3488.

Rossier O, Starkenburg SR and Cianciotto NP (2004) Legionella pneumophila type II protein secretion promotes virulence in the A/J mouse model of Legionnaire's disease pneumonia. Infect Immun 72:310-321.

Russel M (1998) Macromolecular assembly and secretion across the bacterial cell envelope: Type II protein secretion systems. J Mol Biol 279:485-499.

Soderberg MA, Rossier O and Cianciotto NP (2004) The type II protein secretion system of Legionella pneumophila pro- motes growth at low temperatures. J Bacteriol 186:37123720.

Teixeira CT, Oliveira JCF, Novo MTM and Bertolini MC (2008) The cooper resistance operon copAB from Xanthomonas axonopodis pathovar citri: Gene inactivation results in copper sensitivity. Microbiology 154:402-412.

Voloudakis AE, Reignier TM and Cooksey DA (2005) Regulation of resistance to copper in Xanthomonas axonopodis pv. vesicatoria. Appl Environ Microbiol 71:782-789.

Associate Editor: Luis Carlos de Souza Ferreira

License information: This is an open-access article distributed under the terms of the Creative Commons Attribution License, which permits unrestricted use, distribution, and reproduction in any medium, provided the original work is properly cited. 